\title{
A 12-year-old girl presenting with hematemesis, melena and gradual abdominal distension
}

\author{
Mukesh Khadga, Md. Benzamin, Rubaiyat Alam, Nasreen Sultana and Md. Rukunuzzaman
}

\begin{tabular}{|c|c|}
\hline \multicolumn{2}{|c|}{ Article Info } \\
\hline \multicolumn{2}{|c|}{$\begin{array}{l}\text { Department of Pediatric Gastroenterol- } \\
\text { ogy and Nutrition, Faculty of Pediatrics, } \\
\text { Bangabandhu Sheikh Mujib Medical } \\
\text { University, Shahbag, Dhaka, Bangladesh } \\
\text { (MK, MB, RA, MR); National Institute of } \\
\text { Nuclear Medicine and Allied sciences, } \\
\text { Bangabandhu Sheikh Mujib Medical } \\
\text { University, Shahbag, Dhaka, Bangladesh } \\
\text { (NS) }\end{array}$} \\
\hline $\begin{array}{l}\text { For Corresponder } \\
\text { Mukesh Khadga } \\
\text { coolmuks0@gma }\end{array}$ & \\
\hline $\begin{array}{l}\text { Received: } \\
\text { Accepted: } \\
\text { Available Online: }\end{array}$ & $\begin{array}{r}25 \text { January } 2020 \\
29 \text { May } 2020 \\
16 \text { June } 2020\end{array}$ \\
\hline \multicolumn{2}{|c|}{$\begin{array}{l}\text { ISSN: 2224-7750 (Online) } \\
\text { 2074-2908 (Print) }\end{array}$} \\
\hline \multicolumn{2}{|c|}{ DOI: 10.3329/bsmmuj.v13i2.47604 } \\
\hline $\begin{array}{l}\text { Cite this article: } \\
\text { Khadga M, Benza } \\
\mathrm{N} \text {, Rukunuzzamar } \\
\text { presenting with } \\
\text { and gradual a } \\
\text { Bangabandhu She } \\
\text { 2020; 13: 58-62. }\end{array}$ & $\begin{array}{l}\text { M, Alam R, Sultana } \\
\text { A } 12 \text {-year-old girl } \\
\text { atemesis, melena } \\
\text { ninal distension. } \\
\text { Mujib Med Univ J. }\end{array}$ \\
\hline \multicolumn{2}{|c|}{$\begin{array}{l}\text { Copyright: } \\
\text { The copyright of this article is retained } \\
\text { by the author(s) [Atribution CC-By 4.0] }\end{array}$} \\
\hline $\begin{array}{l}\text { Available at: } \\
\text { www.banglajol.in }\end{array}$ & \\
\hline $\begin{array}{l}\text { A Journal of Bang } \\
\text { Medical Universit }\end{array}$ & $\begin{array}{l}\text { dhu Sheikh Mujib } \\
\text { laka, Bangladesh }\end{array}$ \\
\hline
\end{tabular}

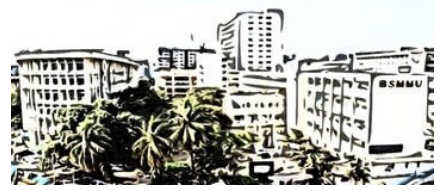

\section{Presentation of Case}

Dr. Md. Benzamin (MD Resident): A 12-year-old girl, $2^{\text {nd }}$ issue of non-consanguineous parents, immunized as per EPI schedule, presented with the history of hematemesis and melena 3 months back and abdominal distension for 1 year. After the episodes of hematemesis and melena, she received 1 unit of blood transfusion. She had no history of fever, jaundice, abdominal trauma, umbilical catheterization, umbilical sepsis, severe dehydration, offending drug intake and abdominal trauma or any surgery.

On general examination, the child was illlooking and severely anemic. The stigmata of chronic liver disease was absent. The vital signs were normal. She was moderately underweight and moderately stunted. On abdominal examination, the abdomen was soft and distended over the left hypochondrium. There was a huge splenomegaly $(14 \mathrm{~cm})$ (Figure 1A). The liver was not palpable. Ascites was absent. Other systemic examination revealed normal findings.

Investigations revealed severe anemia (hemoglobin $5.1 \mathrm{~g} / \mathrm{dL}$ ), thrombocytopenia (platelet count $35,000 / \mathrm{mm}^{3}$ ), leucopenia (total white blood cells 1,500/ $\mathrm{mm}^{3}$ ) (Table I). Peripheral blood film showed microcytic hypochromic anemia with no features of hemolysis. Prothrombin time (12 sec, INR- 1.02), activated partial thromboplastin time and serum albumin level were normal $(56 \mathrm{~g} / \mathrm{L})$. Ultrasonography of the whole abdomen showed coarse hepatic echotexture and huge splenomegaly.

\section{Provisional Diagnosis}

Portal hypertension (extra-hepatic cause)

\section{Differential Diagnosis}

Dr. Mukesh Khadga (Resident): As the patient presented with a history of gastrointestinal bleeding (hematemesis, melena) with gradual abdominal distension and on examination she had anemia, moderate underweight and stunting, huge splenomegaly, ultrasonography of the whole abdomen showed coarse hepatic echotexture and huge splenomegaly. So, we differentially thought of chronic liver disease (compensated) with portal hypertension.

Chronic liver disease (compensated) with portal hypertension

Dr. Mukesh: The term chronic liver disease implies a longstanding irreversible change in the hepatic structure that may end in complications like cirrhosis, portal hypertension leading to premature death. $\underline{1}$ The main etiologies of chronic liver disease are chronic viral hepatitis (Hepatitis-B), Wilson's Disease and autoimmune liver disease. Patients of chronic liver disease with PHTN commonly present with edema, ascites, jaundice, pallor, variceal bleeding, splenomegaly, stigmata of chronic liver disease.? Compensated cirrhosis refers to the condition where hepatic synthetic functions are preserved despite the cirrhosis, in contrast to decompensated cirrhosis, where patients suffer from progressive complications of liver disease (fatigue, ascites, variceal bleeding, hepatic encephalopathy) with associated hepatic dysfunction. $\underline{3,4}$

Dr. Benzamin: Serum alanine aminotransferase (20 U/L), prothrombin time and albumin levels (56 g/L) were normal. The HBsAg was negative. The serum ceruloplasmin level was normal. The eye evaluation for the KF ring and sunflower cataract were negative. The total IgG level was normal and ANA was negative. So, chronic liver disease was excluded.

Dr. Mukesh: Portal hypertension is a disease which occurs due to the formation of portalsystemic collaterals, that shunts a portion of the portal blood flow to the systemic circulation, bypassing the liver. 5 Diagnosis is done by upper gastrointestinal endoscopy. $\underline{6}$

Dr. Rubaiyat Alam (Assistant Professor): To reach our diagnosis we did the upper gastrointestinal endoscopy which showed large varices in the lower part of esophagus. There are several classifications for grading of esophageal 

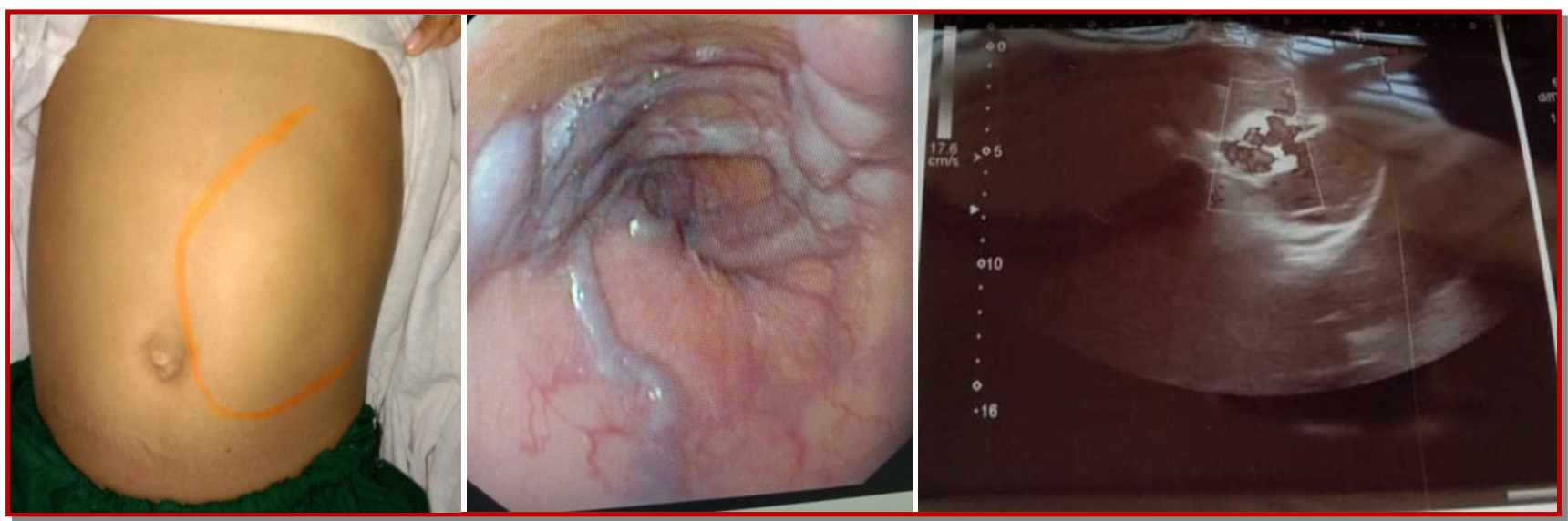

Figure 1: Splenomegaly (A), Grade IV esophageal varices (B), and doppler ultrasonography (C) showing cavernous transformation of portal vein

\begin{tabular}{|c|c|c|}
\hline \multicolumn{3}{|c|}{ Table I } \\
\hline \multicolumn{3}{|c|}{ Laboratory investigations } \\
\hline Investigations & Results & Reference \\
\hline Hemoglobin $(\mathrm{g} / \mathrm{dL})$ & 5.1 & $13-17$ \\
\hline White blood cells $\left(/ \mathrm{mm}^{3}\right)$ & 1,500 & $4,500-5,500$ \\
\hline Platelet $\left(/ \mathrm{mm}^{3}\right)$ & 35,000 & $\begin{array}{r}1,50,000- \\
4,50,000\end{array}$ \\
\hline Peripheral blood film (PBF) & $\begin{array}{r}\text { Microcytic hypo- } \\
\text { chromic anemia with } \\
\text { no features of hemol- } \\
\text { ysis. }\end{array}$ & $\begin{array}{c}\text { Microcytic hypo- } \\
\text { chromic anemia } \\
\text { with no features of } \\
\text { hemolysis. }\end{array}$ \\
\hline Serum albumin $(\mathrm{g} / \mathrm{dL})$ & 5.6 & $3.5-5.5$ \\
\hline Serum bilirubin (mg/dL) & 1 & $0.2-1.2$ \\
\hline Prothrombin time (sec) & 12 & $12-16$ \\
\hline International normalized ratio & 1.02 & $<1.4$ \\
\hline $\begin{array}{l}\text { Serum alanine aminotransferase } \\
(\mathrm{U} / \mathrm{L})\end{array}$ & 20 & $35-50$ \\
\hline Total IgG $(\mathrm{g} / \mathrm{L})$ & Normal & $0-16$ \\
\hline ANA & Negative & Negative \\
\hline Serum ceruloplasmin $(\mathrm{mg} / \mathrm{dL})$ & 35 & $>20$ \\
\hline $\begin{array}{l}\text { Eye evaluation for K-F ring, } \\
\text { sunflower cataract }\end{array}$ & Absent & Absent \\
\hline HBsAg & Negative & Negative \\
\hline
\end{tabular}

varices, like- Dagradi classification, Conn's classification, Paquet's classification, Westaby classification, Soehendra classification, Cale's classification. Paquet's classification for grading of esophageal varices is as follows, Grade I: microcapillaries located in the distal esophagus or esophago-gastric junction, Grade II: one or two small varices located in the distal esophagus, Grade III: medium-sized varices of any number and Grade IV: large-sized varices in any part of the esophagus.? So, according to Paquet's classification, our patient had Grade IV varices (Figure 1B).

Dr. Benzamin: Several etiologies are responsible for

the development of extrahepatic portal hypertension. Among them, the most common cause is extrahepatic portal vein obstruction. 8 So, we did color doppler ultrasonography and it showed cavernous transformation of portal vein with evidence of portal hypertension (Figure 1C).

Nasreen Sultana (Professor): Extrahepatic portal vein obstruction is a primary vascular condition characterized by chronic long-standing blockage and the cavernous transformation of the portal vein with or without additional involvement of intrahepatic branches, splenic or superior mesenteric vein.? It is the predominant cause of pediatric portal hypertension in developing countries. It is a prehepatic type of portal hypertension in which liver functions and morphology are preserved to date.

Doppler ultrasound is an accurate non-invasive method for evaluation of portal hemodynamics that provides valuable information on morphological, qualitative and quantitative changes. $\underline{10}$

In the normal portal vein, spectral doppler ultrasound shows antegrade or hepatopetal flow and a waveform above the baseline. Abnormally slow portal venous flow is diagnostic when peak velocity is less than $16 \mathrm{~cm} / \mathrm{sec}$. In some cases, the flow is still hepatopetal but spectral analysis may demonstrate loss of respiratory phasicity and more pronounced cardiac periodicity which can progress to an absence of end-diastolic flow, arterialized flow or bidirectional to-and-fro flow. Slow or reverse (hepatofugal) flow are two of the most specific findings. Absent flow in the portal vein may be due to stagnant flow in portal hypertension. Recanalization occurs in some cases of thrombosis but more frequently if portal vein thrombosis persists, portal flow is reestablished via cavernous transformation (portal vein undergoes fibrosis and a tangle of tortuous collateral veins are seen along the usual course of the portal vein). The dilated superior mesenteric vein and splenic vein may be seen. In 
some cases, reversed flow may be detected. The most specific finding is the development of portosystemic collaterals. On doppler, collateral vessels demonstrate continuous flow similar to that of the portal vein. The most common sites are paraumbilical vein, gastro-esophageal or short gastric, splenorenal or gastro-renal veins, inferior mesenteric veins. 11

The use of the congestive index has been recommended in helping to diagnose. It is the ratio of the portal vein cross-sectional area divided by the mean portal flow velocity. In the normal subject, this ratio is less than $0.7 . \underline{12}$

\section{Dr. Benzamin's Diagnosis}

Portal hypertension due to extrahepatic portal vein obstruction

The child was treated with endoscopic variceal ligation, blood transfusion followed by Tab. propranolol $1 \mathrm{mg} / \mathrm{kg} /$ day in three divided doses.

\section{Discussion}

Dr. Alam (Assistant Professor): Portal hypertension is defined as portal vein pressure $>5 \mathrm{mmHg}$ or a portal vein to hepatic vein gradient of $>10 \mathrm{mmHg}$. $\underline{13}$

Physical examination is helpful in diagnosis. Splenomegaly is common and sometimes massively enlarged. In extrahepatic portal hypertension no hepatomegaly. In cirrhosis patient, the liver is usually small and shrunken, but children with biliary atresia, the liver may be moderately enlarged. In Budd-Chiari syndrome or congenital hepatic fibrosis, the liver may be massively enlarged. Ascites is generally only present when portal hypertension is at the sinusoidal level. $\underline{14}$

The four main portals to systemic vein collateral systems that become prominent in portal hypertension. Varices developed due to increased pressure in the portal to esophageal and gastric collateral system. Caput medusa result from Increased pressure in the paraumbilical venous network. With overfilling of the perirectal collateral venous system, hemorrhoids appear. $\underline{14}$

Investigations modalities include endoscopy and duplex sonography. The liver function tests along with some common etiology (chronic viral hepatitis, Wilson disease, autoimmune hepatitis, etc.) are essential to exclude the chronic liver disease. Esophageal and gastric varices are best examined by endoscopy. Magnetic resonance angiography is newer, less invasive radiologic techniques. Intravenous computed tomography using a helical CT scanner can be identified as changes in the esophageal and gastric vasculature earlier than endoscopy. $\cdot \underline{15-17}$

Dr. Nazmul Hassan (Resident): What is the differentiating point between EHPHTN and chronic liver disease with portal hypertension?

Dr. Khadga: EHPHTN is usually present on early age with a repeated history of hematemesis and melena, without deteriorating general health condition and absence of stigmata of chronic liver disease. $\underline{6}$

Dr. A. Z. M. Raihanur Rahman: What investigation is done to diagnose portal hypertension, where endoscopy is not available?

Dr. Benzamin: Barium swallow is done. It will show a worm-like filling defect in esophagus. 18

Dr. Nazmul Ahamed (Resident): What is the importance of consanguinity in EHPTH?

Dr. Khadga: Protein C, protein S deficiency is autosomal recessive disease and also one of etiology of extrahepatic portal vein obstruction. $\underline{19}$

Dr. Maimuna Sayeed (Resident): What are the predictors of variceal bleeding?

Md. Rukunuzzaman (Professor): Predictors of variceal bleeding include 1 . Portal vein-hepatic vein gradient $>12 \mathrm{mmHg}$, 2. Large, tense varices, red wale marks, 3. Red spots on varices, 4. Severity of underlying liver disease, 5. Presence of gastric varices and 6. Extrahepatic portal vein obstruction. 14

Dr. Aysha Siddiqua (Resident): What are the prophylactic therapy given to prevent variceal bleeding?

Dr. Khadga: Beta-blocker (propranolol), endoscopic therapy. 6

Dr. Sharmin Akter (Resident): What is primary prophylaxis and what is secondary prophylaxis?

Dr. Benzamin: Prophylactic therapy given before the $1^{\text {st }}$ episode of hematemesis and melena is known as primary prophylaxis and after the episode of hematemesis and melena is known as secondary prophylaxis. 6

Dr. Ferdous Ara Begum (Resident): How propranolol acts?

Dr. Rukunuzzaman: Propranolol is a non-selective $\beta$ blocker. It primarily blocks $\beta_{2}$-adrenoceptors of the splanchnic bed, leaving unopposed a-adrenoceptor stimulation and thus decreased splanchnic and portal perfusion. It also decreases heart rate by $\beta 1$ adrenoreceptor blockade, thus lowering cardiac output and portal perfusion. It also decreases collateral circulation (e.g. azygous vein blood flow). $\underline{6}$

Dr. Sharmistha Ghosal (Resident): What are the endoscopic therapyies available for portal hypertension?

Dr. Benzamin: Sclerotherapy and ligation therapy. $\underline{6}$ 
Dr. Aysha Sabiha (Resident): What is the emergency management for variceal bleeding?

Dr. Khadga: Firstly, management includes maintenance of patients' airway, breathing and circulation, including fluid resuscitation with crystalloids or red blood cell transfusion cautiously. Simultaneously, starting of inj. terlipressin, vasopressin, or somatostatin (octreotide) is equally important. A nasogastric tube is essential and blood/ blood product transfusion if indicated. After stabilization endoscopic therapy and propranolol to prevent further bleeding. If needed, surgical management is the choice. 6

Dr. Bodhrun Nahar (Resident): Why nasogastric tube is given on acute variceal bleeding?

Dr. Benzamin: A nasogastric tube is given to see any active bleeding present or not and removal of blood (a protein source that may precipitate encephalopathy). Moreover, blood in the stomach increases splanchnic blood flow and potentially could worsen portal hypertension and ongoing hemorrhage. 6

Dr. Kaniz Fathema (Resident): What are the indications of blood/blood product transfusion in acute variceal bleeding management?

Dr. Khadga: Packed red blood cells is transfused if the hemogobin level is less than $8 \mathrm{mg} / \mathrm{dL}$, platelet transfusion if $<50,000 / \mathrm{mm}^{3}$. Fresh frozen plasma transfusion if prothrombin time is prolonged. $\underline{6}$

Dr. Khondokar Mobbasher Ahmed (Resident): How is inj. octreotide given and when to stop?

Dr. Benzamin: Inj. octreotide is given $1-2 \mu \mathrm{g} / \mathrm{kg}$ stat at a bolus dose followed by $2-5 \mu \mathrm{g} / \mathrm{kg} /$ hour maintenance dose to continue the infusion for at least 5 days in patients at risk of rebleeding.20,21

Dr. Saidul Sumon (Resident): What are surgical management options for EHPHTN?

Dr. Khadga: The portosystemic shunt procedures include mesocaval shunt, portocaval shunt, splenorenal shunt, meso Rex bypass and splenectomy $\underline{6}$

Dr. Mahmudul Hasan (Resident): Is there any chance of liver function impairment in EHPHTN?

Dr. Benzamin: Liver function may be impaired if there is the development of portal biliopathy.

Dr. Rafiqul Islam (Resident): What advice was given to the patient during discharge?

Dr. Benzamin: Fever, dehydration, constipation and cough should be treated on a priority basis. Propranolol should continue and if there is gastrointestinal bleeding occur. Propranolol should be withheld and hospitalized for emergency management. 22

Dr. Naznin Sarkar (Resident): How will you follow- up with the child?

Dr. Khadga: The follow-up endoscopy is done frequently until small varices are seen. When varices become small, then endoscopy should be done every 1-2 yearly. .3

Dr. Nayma Rahman (Resident): What is the prognosis of extrahepatic portal vein obstruction?

Dr. Benzamin: Regular endoscopic and medical treatment ensure a good long term prognosis. $\underline{24}$

\section{Final Diagnosis}

Portal hypertension due to extrahepatic portal vein obstruction

\section{Conflict of Interest}

Authors declare no conflict of interest

\section{References}

1. Dhole SD, Kher AS, Ghildiyal RG, Tambse MP. Chronic liver diseases in children: Clinical profile and histology. J Clin Diagn Res. 2015; 9: 4-7.

2. Hanif M, Raza J, Qureshi H, Issani Z. Etiology of chronic liver disease in children. J Pakistan Med Assoc. 2004; 54: 119-22.

3. Hsu EK, Murray KF. Cirrhosis and chronic liver failure. In: Liver disease in children. Suchy FJ, Sokol RJ, Balistreri WF (eds). $4^{\text {th }}$ ed. Cambridge, Cambridge University Press. 2014, pp 51-67.

4. Benzamin M, Islam R, Subha NE, Begum F. A 12year old boy presented with jaundice, abdominal distension and leg edema. Bangabandhu Sheikh Mujib Med Univ J. 2020; 13: 22-26.

5. Bosch J, Abraldes JG, Groszmann R. Current management of portal hypertension. J Hepatol. 2003; 38: S54-68.

6. Shneider BL. Portal hypertension. In: Liver disease in children. Suchy FJ, Sokol RJ, Balistreri WF (eds). $4^{\text {th }}$ ed. Cambridge, Cambridge University Press, 2014, pp 68-87.

7. Philips CA, Sahney A. Oesophageal and gastric varices: Historical aspects, classification and grading: Everything in one place. Gastroenterol Rep. 2016; 4: 186-95.

8. Khadga M, Benzamin M, Karim AB. Extrahepatic portal venous obstruction in children: Approach and management. Mediscope 2019; 6: 79-85.

9. Sarin SK, Khanna R. Non-cirrhotic portal hypertension. Clin Liver Dis. 2014; 18: 451-476.

10. Pargewar SS, Desai SN, Rajesh S, Singh VP, Arora 
A, Mukund A. Imaging and radiological interventions in extra-hepatic portal vein obstruction. World J Radiol. 2016; 28: 556-70.

11. Wu CC. Ultrasonographic evaluation of portal hypertension and liver cirrhosis. J Med Ultrasound. 2008; 16: 188-93.

12. Paul A. In: Clinical Doppler Ultrasound. $2^{\text {nd }}$ ed. London, Elsevier Health Sciences. 2006; pp 151-152.

13. Vargas HE, Gerber D, Abu-Elmagd K. Management of portal hypertension related bleeding. Surg Clin North Am. 1999; 79: 1-22.

14. Suzanne V. End-Stage Liver Disease. In: Walker's Pediatric Gastrointestinal disease. Kleinman RE, Goulet OJ, Mieli - Vergani G, Sanderson IR, Sherman MP, Shneider BL (eds). $6^{\text {th }}$ ed. North Carolina, People's Medical Publishing House, 2018, pp 1695-722.

15. Kuroiwa M, Suzuki N, Hatakeyama SI, Takahashi A, Ikeda H, Sakai M, Tsuchida Y. Magnetic resonance angiography of portal collateral pathways after hepatic portoenterostomy in biliary atresia: Comparisons with endoscopic findings. J Pediatr Surg. 2001; 36: 1012-16.

16. Gulati MS, Paul SB, Arora NK, Mathur P, Berry M. Esophageal and gastric vasculature in children with extrahepatic portal hypertension: Evaluation by intravenous CT portography. Clin Imaging. 2000; 24: 351-56.

17. Kozaiwa K, Tajiri H, Yoshimura N, Ozaki Y, Miki K, Shimizu K, Harada T, Okada S. Utility of duplex Doppler ultrasound in evaluating portal hypertension in children. J Pediatr Gastroenterol Nutr. 1995; 21: 215-19.
18. Cho KC, Patel YD, Wachsberg RH, Seeff J. Varices in portal hypertension: Evaluation with CT. Radiographics. 1995; 15: 609-22.

19. Mileti E, Rosenthal P. Management of portal hypertension in children. Curr Gastroenterol Rep. 2011; 13: 10-16.

20. Villanueva C, Miñana J, Ortiz J, Gallego A, Soriano G, Torras X, Sáinz S, Boadas J, Cussó X, Guarner C, Balanzó J. Endoscopic ligation compared with combined treatment with nadolol and isosorbide mononitrate to prevent recurrent variceal bleeding. N Engl J Med. 2001; 345: 647-55.

21. El-Shabrawi MH, Kamal NM. Medical management of chronic liver diseases (CLD) in children (part II): focus on the complications of CLD, and CLD that require special considerations. Paediatr Drugs. 2011; 13: 371-83.

22. Sarin SK, Kumar A, Angus PW, Baijal SS, Chawla YK, Dhiman RK, De Silva HJ, Hamid S, Hirota S, Hou MC, Jafri W. Primary prophylaxis of gastroesophageal variceal bleeding: Consensus recommendations of the Asian Pacific Association for the Study of the Liver. Hepatol Int. 2008; 2: 429-39.

23. De Franchis R, Baveno V Faculty. Revising consensus in portal hypertension: Report of the Baveno $\mathrm{V}$ consensus workshop on methodology of diagnosis and therapy in portal hypertension. J Hepatol. 2010; 53: 762-68.

24. Weiss B, Shteyer E, Vivante A, Berkowitz D, Reif S, Weizman Z, Bujanover Y, Shapiro R. Etiology and long-term outcome of extrahepatic portal vein obstruction in children. World J Gastroenterol. 2010; 16: 4968-72. 